\title{
EFFECT OF SOCIAL MEDIA IN LEARNING PROCESS OF AGRICULTURAL
} GRADUATES

\author{
M. NIRMALA DEVI ${ }^{1}$, S. SELVANAYAKI ${ }^{2}$, S. JAYASRI $^{3} \&$ E. JEEVITHA ${ }^{4}$ \\ ${ }^{I}$ Associate Professor, (Agrl. Extension) Department of Agrl. Extension and Rural Sociology, TNAU, Coimbatore, India \\ ${ }^{2}$ Assistant Professor, (ARM). Dept. of Social Sciences. Forestry College and Research Institute, Mettupalayam, India \\ ${ }^{3,4}$ Project Students, Agricultural College and Research Institute, Vazhavachanur, India
}

\begin{abstract}
Social media is a platform for the younger generation especially for the students to exchange their ideas, feelings and thoughts with their peer groups in an effective manner. These media connect students of various spheres and enable them to use of their benefits in an interchangeable way. This study was conducted using purposeful sampling method at Agricultural collage and Research Institute -Vazhavachanur, Thiruvannamalai district. The sample size is 121 students comprising of third year and final year students of the college. The study revealed that 17.14 per cent of female students have improved very much in knowledge on new courses and knowledge on application software for downloading study materials. General knowledge and thinking ability have improved by 41.41 per cent and 37.14 per cent of the female students respectively. Forty per cent of the students have improved in vocabulary followed by 28.57 per cent in knowledge in subject. The study also revealed that 31.37 per cent of male students have improved very much on multimedia skills followed by 21.56 per cent on general knowledge. This probing investigation indicated that all the students have access to internet facility and they are using social media for both academic and entertainment purpose. The social media are used for sharing study materials and searching assignment topics. The social media not only provide college students another world to make friends, also provides a good way to release pressure. Although the social media has many benefits, it also has negative effect on students' academic purposes. Our research study indicated that an approach is needed to better balance the relationship between social media and academic study. Hence, educators need to be concerned about these problems and try to find better ways to solve these problems.

\section{KEYWORDS: Social Media, Students, Learning Process}

Received: Oct 01, 2020; Accepted: Oct 30, 2020; Published: Nov 10, 2020; Paper Id.: IJESROCT20202

\section{INTRODUCTION}

Social media is a platform for the younger generation especially for the students to exchange their ideas, feelings and thoughts with their peer groups in an effective manner. These media connect students of various spheres and enable them to use of their benefits in an interchangeable way. This digitalised technology has an effective impact on the students' profile by making them exposed to new advanced technologies and enhance their knowledge on those innovations which are applied in their educational domains.

There are studies that aimed at the use of social media by the students for various purposes. "The impact of Social Networking Websites on the education of youth that social media has both harmful and good impact on the learning of the youth."(S.Kuppuswammy, 2010). The pattern of Mobile phone usage and its effect on psychological health, sleep, and academic performance in students of a medical university. The result revealed that "76.4 per cent having smartphones". (Naveenta Gupta et al., 2015). The study of college students using social networking sites networking sites and their relationship with demography profile revealed that 63 per cent and 27 per cent of the 
respondent belongs to urban area and rural area respectively. (Suman Ghalawat et al., 2017)

This study intends to examine the effect of social media in learning process by agricultural graduates. The study revealsCharacteristics of the agricultural graduates, effect of social media on learning process of Agricultural Graduates. The study was taken up with the specific objective of studying the effect of social media on students for academic purpose.

\section{METHODOLOGY}

The study was conducted using purposeful sampling method at Agricultural collage and Research Institute Vazhavachanur, Thiruvannamalai district. The sample size is 121 students comprising of third year and final year students of the college.

The selected variables are age, gender, rural urban difference, medium of instruction, domicile of state, accessibility of students to different social media networks, usage of gadgets to access social network, knowledge of students about social media, and effect of social media for academic purposes and learning process.

The data were collected through a well-structured interview schedule. With the statistical tool of percentage analysis, the data were analysed. The findings were meaningfully interpreted and relevant conclusions were drawn.

\section{FINDINGS AND DISCUSSION}

\section{Profile of the Agricultural Graduates}

More than half of the respondents are female $(57.85 \%)$ students and 42.14 per cent of the respondents are male students.Most of the students are from rural background (70.24\%) out of which 67.14 per cent are female and $74.50 \%$ are male students. Most of the students are from Tamil Nadu (93.38\%) and 6.61per cent students are from other state especially from Andhra Pradesh.All the students have access to the internet. Majority of students possess android phone (86.77\%) followed by mobile phones $(22.31 \%)$ and 5.7 per cent of students possessi phone and 0.826 per cent possessiPads.

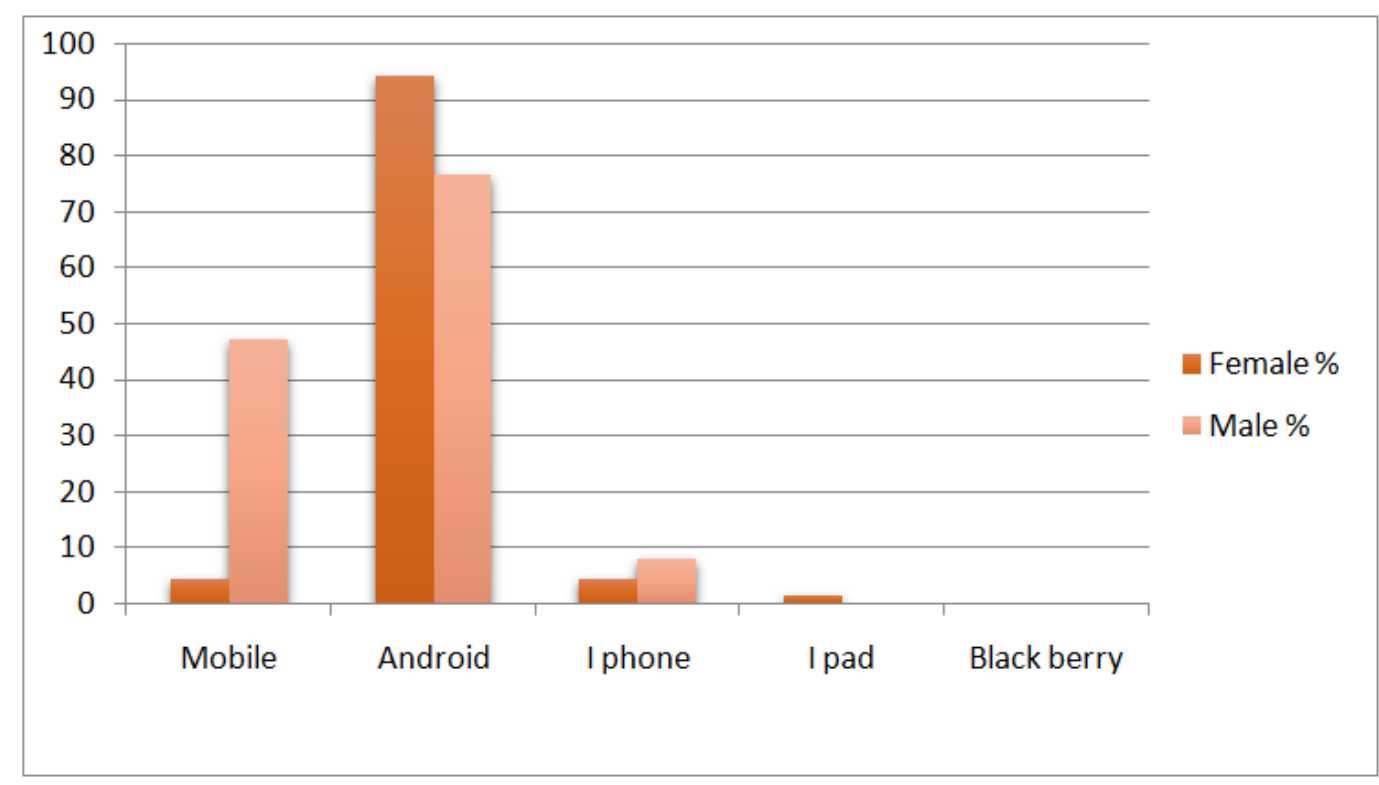

Figure 1: Distribution of Students Based on the Possession of Communication Gadget 


\section{Distribution of Students Based on their Aspiration for Future Career.}

Majority of the students aspired for JRF/PG (23.96\%) and UPSC (22.31\%) among these students male students are comparatively higher than female students to pass through the UPSC exams and to take top administrative jobs.

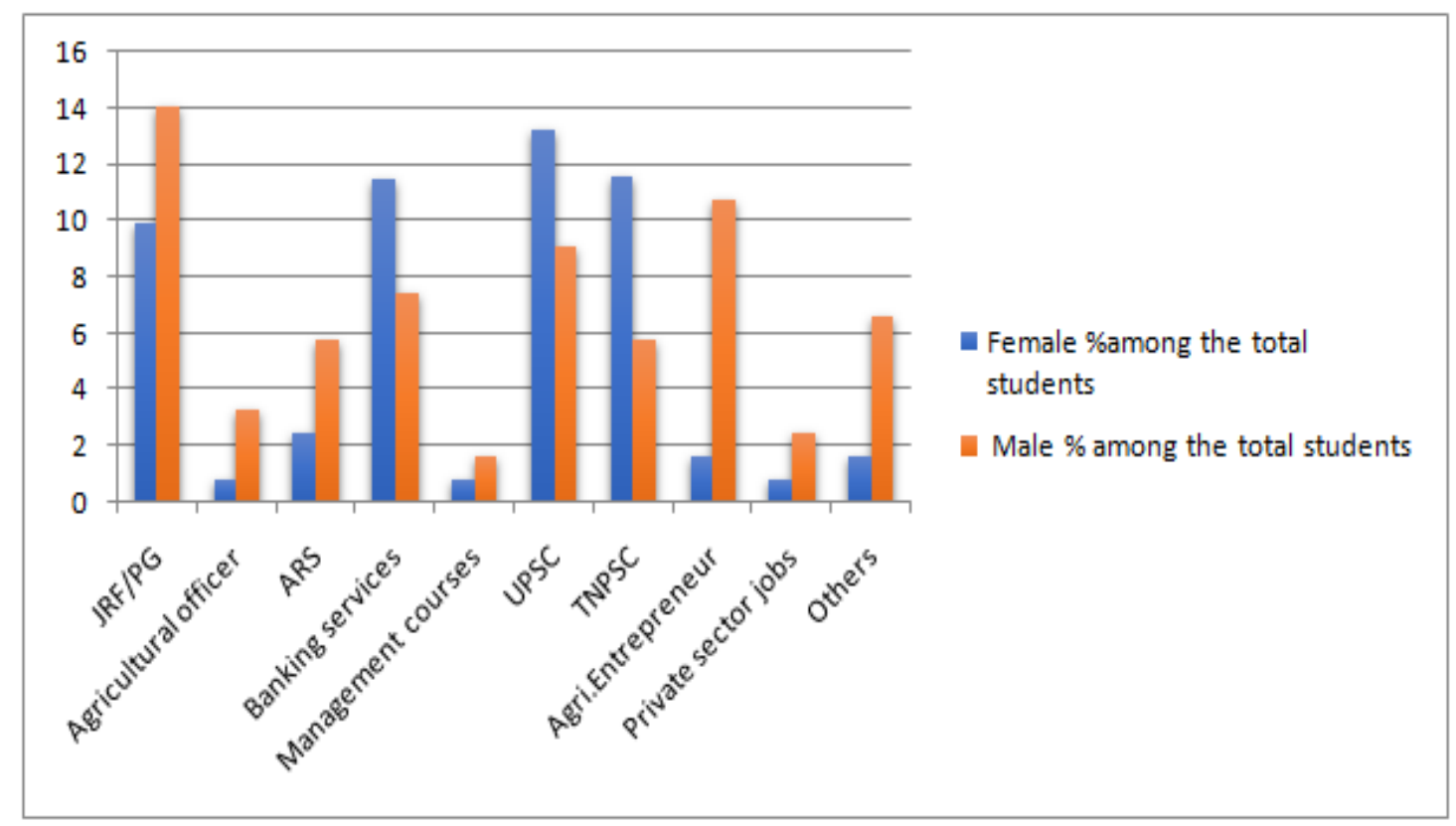

Figure 2: Distribution of Students Based on their Aspiration for Future Career.

\section{SOCIAL MEDIA ACCESSIBILITY}

Table 1: Accessibility of Students to Different Social Media Networks

\begin{tabular}{|l|c|c|c|c|c|c|}
\hline \multicolumn{1}{|c|}{ Accessibility } & \multicolumn{2}{c|}{ Female } & \multicolumn{2}{c|}{ Male } & \multicolumn{2}{c|}{ Total* } \\
\hline & Number & Per cent & Number & Per cent & Number & Per cent \\
\hline Face book & 42 & 60.00 & 43 & 84.31 & 85 & 70.24 \\
\hline WhatsApp & 39 & 55.71 & 46 & 90.19 & 85 & 70.24 \\
\hline Hike & 8 & 11.42 & 19 & 37.25 & 27 & 22.31 \\
\hline Telegram & 8 & 11.42 & 17 & 33.33 & 25 & 20.66 \\
\hline Imo & 4 & 05.71 & 9 & 17.64 & 13 & 10.74 \\
\hline Twitter & 4 & 05.71 & 22 & 43.13 & 26 & 21.48 \\
\hline Skype & 1 & 01.42 & 9 & 17.64 & 10 & 08.26 \\
\hline Fb messenger & 12 & 17.14 & 27 & 22.94 & 39 & 32.23 \\
\hline Others & 3 & 04.28 & 5 & 09.80 & 8 & 06.61 \\
\hline
\end{tabular}

*Multiple response

It is seen from the table majority of students have account in Facebook and WhatsApp (70.24\%) followed by Fb messenger $(32.23 \%)$ and it is found to be higher among male students $(22.94 \%)$.Hike is accessed by 22.31 per cent students and IMO by 10.74 per centstudents. Some of the students have access to multiple social networking sites. 


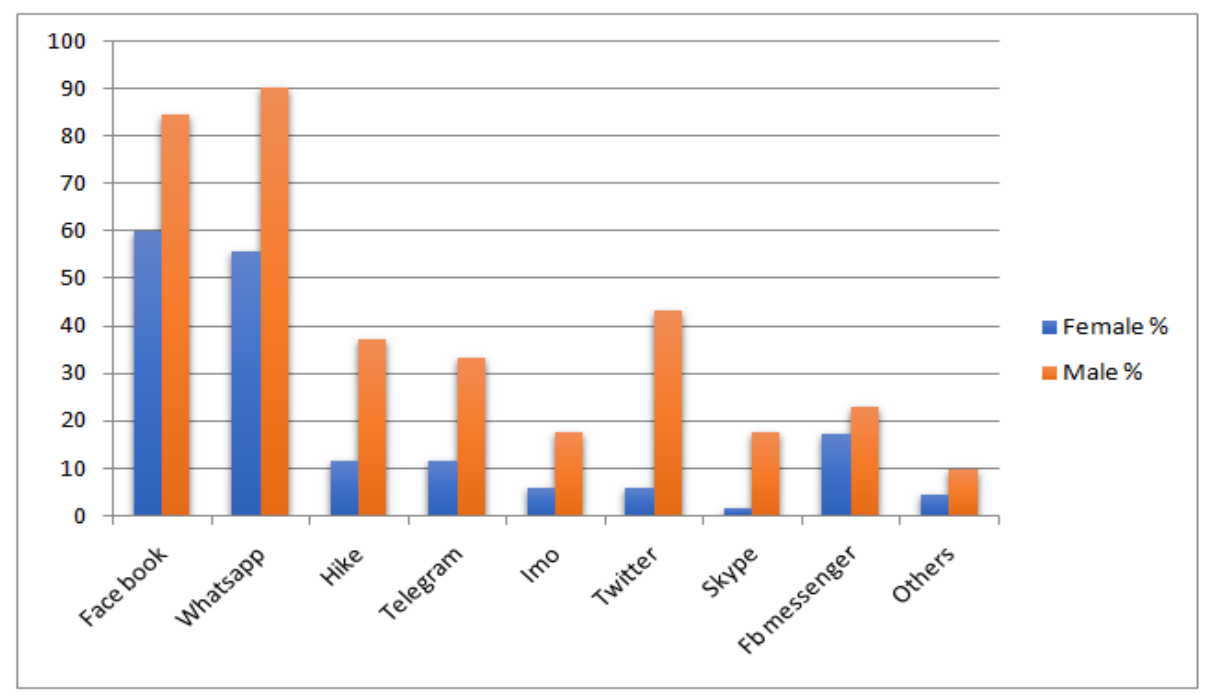

Figure 3: Accessibility of Students to Different Social Media Networks

\section{EXTENT OF USAGE OF SOCIAL NETWORKING SITES}

The study revealed that 60 per cent and 44 per cent of the female students are daily using internet for chatting and finding meanings of the words respectively. They are using internet for assignment purpose also. The study revealed that 50.98 per cent of the male students are daily using internet.

A majority of 55.71 per cent of the female students are using social media for entertainment for 1-2 hrs per day and this is followed by 51.42 percent for learning purpose and 41.42 per cent for assignment purpose.

\section{EFFECT OF SOCIAL MEDIA ON LEARNING PURPOSE}

The study showed that 17.14 per cent of female students have improved very much in knowledge on new courses and knowledge on application software for downloading study materials. General knowledge and thinking ability have improved by 41.41 per cent and 37.14 per cent of the female students respectively. Forty per cent of the students are improved in vocabulary followed by 28.57 per cent in knowledge in the subjects.

Table 2: Effect of Social Mediaon Learning Purpose (Female Students)

\begin{tabular}{|c|c|c|c|c|c|c|c|c|c|c|c|c|c|}
\hline \multirow{3}{*}{ S. No } & \multirow{3}{*}{ Purpose } & \multicolumn{12}{|c|}{ Effect of Social Media in Female Students } \\
\hline & & \multicolumn{2}{|c|}{$\begin{array}{l}\text { Improved } \\
\text { Very Much }\end{array}$} & \multicolumn{2}{|c|}{ Improved } & \multicolumn{2}{|c|}{$\begin{array}{l}\text { Improved } \\
\text { Some What }\end{array}$} & \multicolumn{2}{|c|}{ Improved Little } & \multicolumn{2}{|c|}{$\begin{array}{c}\text { No } \\
\text { improvement }\end{array}$} & \multicolumn{2}{|c|}{$\begin{array}{c}\text { Have gone } \\
\text { down than } \\
\text { before }\end{array}$} \\
\hline & & No & $\%$ & No & $\%$ & No & $\%$ & No & $\%$ & No & $\%$ & No & $\%$ \\
\hline 1 & Vocabulary & 4 & 05.71 & 19 & 27.14 & 28 & 40.00 & 16 & 22.86 & 2 & 02.85 & 0 & 0.00 \\
\hline 2 & Writing skills & 3 & 04.28 & 15 & 21.42 & 17 & 24.28 & 19 & 27.14 & 12 & 17.14 & 2 & 02.85 \\
\hline 3 & Knowledge in subject & 11 & 15.71 & 20 & 28.57 & 20 & 28.57 & 14 & 20.00 & 1 & 01.42 & 1 & 01.42 \\
\hline 4 & General knowledge & 9 & 12.85 & 29 & 41.42 & 17 & 24.28 & 12 & 17.14 & 2 & 02.85 & 0 & 0.00 \\
\hline 5 & $\begin{array}{l}\text { Knowledge on New Career } \\
\text { opportunities }\end{array}$ & 12 & 17.14 & 24 & 34.28 & 13 & 18.57 & 14 & 20.00 & 5 & 07.14 & 0 & 0.00 \\
\hline 6 & $\begin{array}{l}\text { Knowledge about new } \\
\text { courses }\end{array}$ & 14 & 20.00 & 22 & 31.42 & 9 & 12.85 & 18 & 25.71 & 5 & 07.14 & 0 & 0.00 \\
\hline 7 & Multimedia skills & 6 & 08.57 & 19 & 27.14 & 17 & 24.28 & 14 & 20.00 & 9 & 12.85 & 0 & 0.00 \\
\hline 8 & $\begin{array}{l}\text { Knowledge on application } \\
\text { software for downloading } \\
\text { study materials }\end{array}$ & 14 & 20.00 & 25 & 35.71 & 12 & 17.14 & 7 & 10.00 & 8 & 11.42 & 0 & 0.00 \\
\hline 9 & Creativity in writing & 4 & 05.71 & 17 & 24.28 & 15 & 21.42 & 20 & 28.57 & 8 & 11.42 & 1 & 01.42 \\
\hline 10 & Thinking ability & 5 & 07.14 & 26 & 37.14 & 19 & 27.14 & 8 & 11.42 & 5 & 07.14 & 1 & 01.42 \\
\hline 11 & Others & 3 & 04.28 & 5 & 07.14 & 1 & 01.42 & 2 & 02.85 & 3 & 04.28 & 0 & 0.00 \\
\hline
\end{tabular}

Multiple response 
Table 3: Effect of Social Media on Learning Purpose (Male Students)

\begin{tabular}{|c|c|c|c|c|c|c|c|c|c|c|c|c|c|}
\hline \multirow{3}{*}{$\begin{array}{l}\text { S. } \\
\text { No }\end{array}$} & \multirow{3}{*}{ Purpose } & \multicolumn{12}{|c|}{ Effect of Social Media in Male Students } \\
\hline & & \multicolumn{2}{|c|}{$\begin{array}{c}\text { Improved } \\
\text { Very } \\
\text { Much } \\
\end{array}$} & \multicolumn{2}{|c|}{ Improved } & \multicolumn{2}{|c|}{$\begin{array}{c}\text { Improved } \\
\text { Some What }\end{array}$} & \multicolumn{2}{|c|}{$\begin{array}{l}\text { Improved } \\
\text { little }\end{array}$} & \multicolumn{2}{|c|}{$\begin{array}{c}\text { No } \\
\text { Improvement }\end{array}$} & \multicolumn{2}{|c|}{$\begin{array}{c}\text { Have gone } \\
\text { down than } \\
\text { before }\end{array}$} \\
\hline & & No & $\%$ & No & $\%$ & No & $\%$ & No & $\%$ & No & $\%$ & No & $\%$ \\
\hline 1 & Vocabulary & 10 & 19.60 & 12 & 23.52 & 9 & 17.64 & 16 & 31.37 & 3 & 05.88 & 0 & 0.00 \\
\hline 2 & Writing skills & 3 & 05.88 & 13 & 25.49 & 14 & 27.45 & 5 & 09.80 & 10 & 19.60 & 3 & 05.88 \\
\hline 3 & $\begin{array}{l}\text { Knowledge in } \\
\text { subject }\end{array}$ & 10 & 19.60 & 15 & 29.41 & 19 & 37.25 & 4 & 07.84 & 3 & 05.88 & 0 & 0.00 \\
\hline 4 & $\begin{array}{l}\text { General } \\
\text { knowledge }\end{array}$ & 11 & 21.56 & 17 & 33.33 & 14 & 27.45 & 9 & 17.64 & 1 & 01.96 & 0 & 0.00 \\
\hline 5 & $\begin{array}{l}\text { Knowledge on } \\
\text { New Career } \\
\text { opportunities }\end{array}$ & 9 & 17.64 & 16 & 31.37 & 17 & 33.33 & 7 & 13.72 & 2 & 03.92 & 0 & 0.00 \\
\hline 6 & $\begin{array}{l}\text { Knowledge } \\
\text { about new } \\
\text { courses }\end{array}$ & 8 & 15.68 & 17 & 33.33 & 15 & 29.41 & 9 & 17.64 & & 0.00 & 0 & 0.00 \\
\hline 7 & $\begin{array}{l}\text { Multimedia } \\
\text { skills }\end{array}$ & 16 & 31.37 & 18 & 35.29 & 10 & 19.60 & 4 & 07.84 & 3 & 05.88 & 0 & 0.00 \\
\hline 8 & $\begin{array}{l}\text { Knowledge on } \\
\text { application } \\
\text { software for } \\
\text { downloading } \\
\text { study materials }\end{array}$ & 15 & 29.41 & 17 & 33.33 & 9 & 17.64 & 6 & 11.76 & 2 & 03.92 & 0 & 0.00 \\
\hline 9 & $\begin{array}{l}\text { Creativity in } \\
\text { writing }\end{array}$ & 7 & 13.72 & 9 & 17.64 & 16 & 31.37 & 11 & 21.56 & 4 & 07.84 & 2 & 03.92 \\
\hline 10 & $\begin{array}{l}\text { Thinking } \\
\text { ability }\end{array}$ & 11 & 21.56 & 14 & 27.45 & 13 & 25.49 & 6 & 11.76 & 2 & 03.92 & 3 & 05.88 \\
\hline 11 & Others & 6 & 11.76 & 2 & 03.92 & 6 & 11.76 & & 0.00 & 1 & 01.96 & 2 & 03.92 \\
\hline
\end{tabular}

The study revealed that 31.37 per cent of male students have improved very much on multimedia skills followed by 21.56 per cent on general knowledge, knowledge on application software for downloading study materials, knowledge about new courses and general knowledge have improved by 33.33 per cent of the students and 37.25 per cent of the male students have improved in knowledge about the subjects.

\section{CONCLUSIONS}

This probing investigation indicated that all the students have access to internet facility and they are using social media for both academic and entertainment purpose. The social media are used for sharing study materials and searching assignment topics. The social media not only provide college students another world to make friends, also provides a good way to release pressure. Although the social media has many benefits, it also has negative effect on students' academic purposes. Our research study indicated that an approach is needed to better balance the relationship between social media and academic study. Hence, educators need to be concerned about these problems and try to find better ways to solve these problems.

\section{REFERENCES}

1. Dr.Suman Ghalawat, Dr.Sunitha Mehla, Dr.Amita Girdhar, 2017. A study of college students using social networking sites and their relationship with demography profile. BVIMSR's Journals of Management Research. 9 (1):37-39. 
2. YADAV, AMITA. "Attitude of students towards agriculture as a profession." International Journal of Agricultural Sciences and Research 6.6 (2016): 177-182.

3. Naveen Gupta, Sonia Garg and Khushdeep Arora, 2015.Pattern of mobile phone usage and its effects on psychological health, sleep and academic performance in students of a medical university. National Journal of Physiology, Pharmacy and pharmacology. 6(2):135-138.

4. S.Kuppuswammy, 2010. The Impact of social networking websites on the education of youth. BVIMSR's Journals of Management Research.Vol.9 (1): .39-44.

5. Bairwa, Shoji Lal, Saket Kushwaha, and Chandra Sen. "Problems faced by agripreneurs in starting and operating agriventures under ACABCS scheme in Rajasthan state." International Journal of Agricultural Science and Research 5.2 (2015): 203-208.

6. Tarakeswara Rao, 2018. An exploratory study of gender differences in social network communication among undergraduate men and women. International Journal of Management and social science Research (IJMSSR).7(1):23-25.

7. Bairwa, Shoji Lal, Meera Kumari, and L. K. Meena. "Developing mobile based agri retailing (MBAR) model for high value agricultural and livestock products." International Journal of Agricultural Science and Research (IJASR), 5 (6): 125130 (2015).

8. Urista et.al, 2009. Explaining why young adults use My Space and Facebook through uses and gratification theory, Human communication.12 (2):215-229.

9. Duhan, Anju, and Meenakshi Dhingra. "Association between the factors affecting awareness level of farmers about agriculture insurance in Haryana." Int. J. Bus. Gen. Manage 7.1 (2018): 17-24. 